\title{
Museums and Communication: The Case of the Louvre Museum at the Covid-19 Age
}

\author{
Lara Corona ${ }^{1}$ \\ ${ }^{1}$ Universitat Internacional de Catalunya (UIC Barcelona), Spain \\ Correspondence: Lara Corona, Universitat Internacional de Catalunya (UIC Barcelona), Spain. ORCID: 0000- \\ 0003-2602-9023.
}

Received: December 14, 2020; Accepted: January 4, 2021; Published: January 8, 2021

\begin{abstract}
In the last few decades, modern technology has changed the way people communicate. Owing to being an integral part of society, museums have also been influenced by this phenomenon. This paper aims to provide a general overview of the main communication tools, such as social media and the website. This work's purpose is to highlight how museums can reach a bi-directional communication that allows society to maintain a certain interaction with visitors, even in periods when physical access to the collections is not possible. In order to achieve this goal, the essay deals with the adoption of the main tools of modern communication by the Louvre Museum in Paris. It sets out the usage of Instagram, Facebook and the louvre.fr website and highlights the feedback before and after the lockdown occurred due to the Covid-19 virus.
\end{abstract}

Keywords: communication, museums, digitalized collection, social media, virtual museum, Louvre

\section{Introduction}

Since the birth of the World Wide Web, museums have been dealing with digital activities in order to increase their strategic role in communication and public engagement. In the beginning, there were only museum web portals to be managed to make them more interactive and user-friendly. Eventually, there have also been social media platforms, whose relevance cannot be ignored by museums. (Michela Zingone, 2019) The digital revolution has affected museums which reshaped their approach to public engagement, education and marketing. (Monika Stobiecka, 2019) The outbreak of the Covid-19 has affected all sectors, including museums that have developed many initiatives through their social media accounts.

\section{State of the Art}

Some authors have faced the topic of technology within museums, especially as tools to achieve effective communication skills. Amongst the contributors, a recent contribution has been provided by Nicolette Mandarano who offers a picture of main social media. She focused on the figure of prosumers as an active part of the relationship between museums and visitors. (Note 1) Additionally, she reported how museums should communicate adequately. For that reason, she suggested some basic rules that museums should observe. (Note 2) Moreover, she pointed out that modern communication tools might be favourably used when there is criticism around museums in order to figure out the reason for it.

Another significant contribution was provided by Fuentetaja and Economou, who outlined how museums have been using web tools differently. (Ion Gil-Fuentetaja \& Maria Economou, 2019) They concluded that the type of content provided depends on the philosophy of communication of the museum itself. Therefore, social media are the identity of the museum itself. Besides them, De Gottardo, Gasparotti and D'Eredità highlighted how this new communication manner has changed its shape over time. (2014) They argued that communication has already existed before social media appearance. According to these authors, social media are the natural evolution of traditional social networks. Due to Web 2.0, top-down communication has been replaced by word of mouth. (Note 3) Their contribution has been significant since underlines a modern way of visitors' engagement that provides instant feedback for institutions.

The connection between the social media and the museum site was discussed by Weilenmann et al. (2013) They pointed out that Instagram stressed the fact social media allow to build a new typology of communication, regardless the physical location of the museum. Another relevant contributor was Linda Kelly, who studied how museums used social media to improve two-way communication between museums and their audience as well as 
a marketing practice. (Linda Kelly, 2013) She explained why it is crucial to give a proper interpretation of social media feedback in order to manage the Institution according to an attempt of improvement. The social media study as marketing tools was studied in depth by Kotlers, who reported their usage mainly for exhibitions and events. (Neil Kotler et al., 2008) Moreover, the relationship between museums and visitors was studied by Stuedahl and Smordal. The authors underlined how museums had created contents due to the audience's input. The connection between Institution and online users, hence, creates a process where museum activities are conceived by previous feedback of the audience. (Ole Smordal \& Dagny Stuedahl, 2011)

The impact of the Covid on museums was studied in depth by Antara and Sen who stressed how the pandemic has affected all economic sectors that are currently endangered. (Neel Antara \& Shuvro Sen, 2020) Furthermore, a survey of the impact of coronavirus on museums was carried out by NEMO. (Network of European Museum Organisations, 2020) Alberto del Bimbo provided another important contribution to the subject. He stated that Covid 19 has just increased the speed of the evolution of the digital usage process within museums. (Alberto Del Bimbo, 2020) He dealt with social media, augmented reality as well as virtual tours. Some case studies were carried out on the digital activities' usage during the lockdown. Burke, D. Jørgensen and F. Jørgensen wrote how museums responded to pandemic coronavirus through digital initiatives. They dealt with the Louvre Museum as well. Nevertheless, this study just mentioned the fact that the French Institution offered tours on its platforms. (Verity Burke et al., 2020)

Therefore, previous studies have shown how modern technologies, primarily through social media, have changed and improved communication between museums and the audience. Additionally, some case studies were carried out on the usage of digital tools used by museums during the pandemic. With regard to the Louvre Museum, the topic of the digital shift has been studied by some scholars. The authors Evrard and Krebs investigated whether the real and virtual visit integrated or substituted each other. They concluded that there is no equivalence between the digital experience and the visit to a museum. (Yves Evrard \& Anne Krebs, 2013) Nevertheless, this study does not cover the pandemic time. Furthermore, a recent contribution to the usage of Instagram from the Louvre Museum was provided by Michela Zingone. (Michela Zingone, 2019) However, this study limiting to Instagram profile reported a qualitative analysis of the Instagram posts. Moreover, she did not face the pandemic issued as dated back before it. Thus, the present essay aims to fill the literature gap since it covers a time from before the Coronavirus' first wave to after it, meaning to the end of the year.

\section{Goals and Methodology}

The purpose of this paper is to find out whether museums used more these tools during the pandemic' first wave than before it in order to keep in contacts with the general public. Moreover, the work aims to provide a picture of the audience feedback. In order to fulfil these goals, the social media and the website are briefly described, and some meaningful usages in the past are set out. Additionally, this essay's methodology utilizes a case study approach. Therefore, it analyses how the Covid-19 lockdown affected the usage of the technology from the Louvre Museum in Paris and the public's interaction. For this purpose, it was adopted a methodology based on a quantitative approach. (Note 4) This study's data was gathered from the Instagram profile, the Facebook page, and the French museum's official website. In order to figure out their trend before and after the lockdown due to the Covid-19, Louvre's main social media and the web site were observed over time. The process of collecting data from Instagram account took fifteen months from September 2018 to December 2020. The Facebook account figures concern both the number of posts provided by the Institution and the audience's feedback from December 2019 to December 2020. Figures are represented to provide a picture of the evolution of social media usage from the Institution, and the feedback from the audience. Therefore, the analysis covers a time frame that provides a picture of social media usage before the first coronavirus' wave and after that. Finally, the website monitoring carried out through the SimilarWeb software covers a seven-month-time from the time the museum was closed to its opening and sequentially reopening.

\section{Social Media}

Social platforms are now part of the daily life of many people, both young and old. Considering that young people will come to constitute future consumers, museums have well thought of addressing them too through a communication style that is closer to their way of being today, meaning an informal, immediate and brief style. The social media allow people to put in communication several people and insitutions located in different parts of the world and are well suited to museums' communication.

But what are social media? According to the definition developed by De Gottardo and Gasparotti, they are nothing more than "an online service for building virtual communities of people who share the same interests." (Francesca De Gottardo et al., 2014) 
Social media allow people to communicate no longer only in a unidirectional way but involve the majority of people who are totally engaged in it thanks to the birth of Web 2.0 which allows the interaction of masses of people. These applications require the use of the Internet that allows the creation and exchange of user-generated content in which the user from the consumer has become a producer.

The museum is, by definition, participation: through social media the so-called widespread participation is really achieved, passing from the theory of definition to practice, giving voice to "followers", in a "manifest" way, that is accomplished, through a messaging system, or in "unmanifest" way, i.e., through likes, the number of views, etc.

Social media allow communication with the large masses, and this is also valid for small museums which, historically, are significantly affected by the negative economic situation of this historical moment. For instance, many Italian museums belonging to the municipal public administrations notoriously have to fight with a stability pact and other regulatory constraints. For these reasons, they do not have great resources to allocate to large investments concerning culture. For these museums, social media represented a real turning point, a tool that allowed them to implement communication strategies capable of involving, compared to their small size, a rather large catchment area.

Certainly, it can be argued that the fact that the presence of museums through the new communication tools has increased does not necessarily translate into an increase of effective interest in cultural heritage. In general, it is shown that the public is appreciating the use of modern technologies by museums; what is not proven is whether "people are more interested in technology and not in art." (Lara Corona, 2020)

The data relating to the use of social media has been recently highlighted in the annual report "Global digital 2020April": this is a survey conducted by "We are Social" in collaboration with the social media management platform "Hootsuite." (Note 5) The report processed data from two hundred forty-eight countries worldwide, highlighting the fact that the number of users who connect to the Internet has exceeded four and a half billion people. More than half of the people living in the world are equal to almost eight billion people. In April 2020, in the midst of the Covid 19 pandemic, more than four and a half billion people connected to the Internet, which is strictly surprising considering the fact that the survey also includes countries in Africa where particularly convenient tariff plans have been only recently introduced. According to the data of the report, it would seem that the Internet has, in terms of hours spent per capita per day, actually replaced television with an average of more than six hours a day per person of online connection, two of which on social media, mainly via tablets or smartphone. More than five billion are unique mobile phone users.

Surprising is the case of the Salinas Museum in Catania which, even before the outbreak of the virus pandemic, closed for restoration, was able to maintain an active relationship with the public. These are works carried out from July 2011 to July 2016. The museum has implemented communication strategies that have focused on social media that has created a true digital community characterized by the fact that the "followers" are increasingly active users. The slogan chosen by the museum on social media fits well, namely "closed for restoration, open for vocation. (Elisa Bonacini, 2016)

a) Facebook.

Particularly relevant is Facebook, social media that holds the sceptre among social networks with almost 2.1 billion users. Facebook allows users to share images, videos and links, with the possibility of interacting via messaging, promoting events and more. This means of communication has gradually taken on the role of an official communication channel. (Note 6)

The management of this social tool has both advantages and disadvantages. On the one hand, it can undoubtedly be stated that it is a tool that has high versatility and reaches a high number of subscribers, thus allowing to disseminate contents immediately without having to incur high management costs other communication systems. On the other hand, the management of Facebook turns out to be quite demanding since it requires constant supervision, further increased if users are given the possibility to post in turn within the page. The fact that a constant presence is needed, in fact, "forces" to post with a certain regularity, while being careful not to exceed, leads to the so-called spam effect with the subsequent consequence of not following the museum anymore. It is necessary to be careful not only to the "how often", but also to the "how much" because this too would lead to an escape of the "friends" of Facebook. During the pandemic, the St. Petersburg Hermitage Museum used this social network to showcase Raphael and other great masters' chefs-oeuvres. (Claudia Giraud, 2020) 


\section{b) Instagram.}

Instagram has magnified its presence in the world scenario, with almost one trillion active users. It is a tool that allows users to share posts with images and videos with the possibility of interacting through messaging. (Note 7)

It is particularly popular with young people who make up the so-called "followers" and is often used by museums to promote internal initiatives. Indeed, even in this case, particular attention must be paid to both the quality of the images and the text and constantly posting to keep alive the link with own followers.

Museums have the opportunity to have feedback on the appreciation of their posts in real-time thanks to the fact that Instagram offers the possibility of counting the likes, i.e., the public's preferences, followers or not.

\section{The Web Site}

The World Wide Web, referred to as www, developed throughout the 1990s and museums, like any other company, have used this technology. Elena Villaespesa and Trilce Navarrete emphasised that the World Wide Web promised to be a new technology tool that allowed a new communication featured by worldwide access to content. (Villaespesa, Elena, 2019) The Internet is today what the advent of electricity represented in the past. About the increased number of Internet connections, museums have sought, in order to attract ever more masses, to improve their visibility through websites.

Everything is linked to the spread of the first computers in the 1980s, starting from the best-selling Commodore 64. The presence of museums on the web has evolved over time, also in relation to the fact that technology has also been implemented. The first museum websites were the Science Museum in 1997, the National Gallery in 1998 and the Tate in 2000. (Suzanne Keene, 2014)

Initially, it was possible to publish only texts, non-high-definition images, and the problem of speed, problems now overcome thanks to broadband and the use of optical fibre. Museum websites are now very rich in information. For some of them, they are, alas, too much!! There are also high-definition videos and interesting links.

The website can be considered as the visiting card of a museum. Having a good website increases the possibility that the users' virtual visit will result in any action, from the simple subscription to the newsletter, to purchase a ticket or a merchandising product. (Sabina Rosso et al., 2016) The website provides important information such as the indication of the physical location of the museum, means of transport that allow it to be reached, opening hours to the public, tariff table with the indication of any reductions for particular categories (for example over sixty-five, or children up to twelve years, students' exceptions), programming of permanent exhibitions, temporary exhibitions and events.

Furthermore, through the website, the potential visitor can buy the ticket online and thus eliminate the long lines under the sun. Obviously, this is the result of technological advances not even remotely imaginable until recently, yet now part of everyone's daily life.

This type of technology is closely linked to the characteristics of the typology of potential users. In Italy, six different types of users can be identified, indicated following an order linked to the propensity to adopt new technologies: (Paolo Savona et al., 2020)

- the pioneers, who represent seven per cent of the population between the ages of 14, fourteen and seventy-four; they are particularly mobility-oriented people with a high level of culture and socio-economic conditions.

- techno ludens who represent twenty per cent of the population between the ages of fourteen and seventy-four; these are people who have a playful relationship with technology, especially men under thirty with a high concentration among adolescents and in possession of a medium to high culture.

- techno pragmatists who represent twenty per cent of the population between the ages of fourteen and seventyfour; they are people with a neutral relationship concerning mobility and a medium-high level of culture and socioeconomic conditions.

- the techno videns who represent eighteen per cent of the population between the ages of fourteen and seventyfour; these are people who associate technology with a status value without having the basis to be able to use it, with age between thirty and sixty years and low culture and socio-economic conditions.

- the techno-basic which represent eighteen per cent of the population between the ages of fourteen and seventyfour; these are people with basic technology skills, between forty and sixty years old of average culture and middle social class. 
- the excluded and frightened who represent seventeen per cent of the population between the ages of fourteen and seventy-four; these are people who for reasons of low cultural and income level are in a situation of exclusion from technology use. Older people with poor schooling mainly belong to this category.

With regard to the category of users of pioneers, techno ludens and techno pragmatists, the involvement is more marked. At the same time, there is a real detachment relative to users included in the category of techno videns, techno basic, as well as the excluded and frightened.

In addition to general information, a good site presents a sort of preview of the main works exhibited inside the museum, particularly for the most prominent ones. For example, the National Museum of Art located in Krakow in Poland did leverage the exhibition of the famous painting by the authoritative and famous Italian artist Leonardo da Vinci, "Lady with an Ermine".

The website is an important marketing tool as well as a communication and educational tool. Its proper usage contributes to the dissemination of collections since it is accessible from everywhere. (Trilce Navarrete, 2018) For this reason, the design of museum websites requires special care. For this reason, the Ministry for Cultural Heritage and Activities coordinated the "Minerva" project which also involved other European partners starting from 2002. It led to the development of the "Manual for the quality of public cultural websites". (Fedora Filippi, 2004)

Regarding Italy, the Minerva working group has expressed a positive opinion in relation to some case studies such as for the cultural heritage site of the Region of Sardinia as it is suitable for "promoting coordination through the web tool, interoperability and meaning of belonging among the peripheral institutes ... and to create a point of collection and dissemination of information of a cultural nature, concerning the protection, restoration and use of assets, and the promotion of educational activities in the sector. (Note 8)

Museums are proceeding with constant digitization of their artistic heritage, i.e., the digital reproduction of works of art, thus allowing their dissemination, leading to the involvement of a greater number of people. How high-level digital archives are being created. They allow immediate access to the assets belonging to the museum collection with a whole range of information.

The digitization of the heritage requires the need to use specific software which, according to the personal evaluation of each museum, are created within the museum itself through its own programmers, i.e., in-house, or through external purchase according to a ready-made package or according to the indications of the museum staff. The important thing to highlight here is that digitization, born as an internal organizational operation, has become an important communication tool as it has allowed the general public to use it.

The British Museum in London has put nearly four and a half million works from its collection online. (Note 9) In Madrid, the Prado Museum has made available over twelve thousand works in its digital archive, freely available online. In New York, the MoMA has provided for the digitization of over seventy-nine thousand works in September 2018, which appear to be available, become more than eighty-nine thousand in December 2020, for online consultation, by anyone. (Note 10)

Another quite important example is the activity carried out in the Getty Museum in Los Angeles, where the importance of the digital collection of information has led to represent the collection of works of art that have been digitized, which is where it derived. The ability to physically see the works of art, but also the ability to access images and information about the entire collection by simply accessing the Los Angeles Getty Museum website. Numerous museums are moving in this direction.

What is relevant is that the digital transformation is leading to a change in consumer habits. Society itself has changed and imposes this change in museums. The museum's change creates a different bond with young people, and digitization also brings young people closer to museums through the online shop, a tool particularly used by young people.

The technology through the collection of digital data allows museum to realize one of its institutional purposes, that is the use of the cultural asset. Still, it also allows the sale of its products online. The ability to buy something, not necessarily during the visitor's experience on-site and immediately, can also be developed comfortably from their home from their personal computer or anywhere else with a smartphone or tablet.

In order to broaden the visitor profile through alternative canals, some virtual tools enable to disseminate collections have been developed, such as Wikipedia and Google Arts \& Culture. (Note 11) Google has created several virtual galleries that allow, for example, to be able to see works by Paul Gaugin. An interesting journey was carried out by the Staatsgalerie of Stuttgart in Germany where the works of Oskar Schlemmer, master of the Bauhaus, well-known painter, sculptor and choreographer, are digitized, to whom Google has dedicated a doodle for his fiftieth birthday. Google Arts \& Culture, on the basis of the digital archives of the museums, has created 
various virtual galleries that allow, for example, to be able to see works by Paul Gaugin, Monet, except in detail thanks to the magnifying glass function.

Google Arts \& Culture was widely used during the coronavirus pandemic by museums worldwide, such as the British Museum in London. Museum websites were heavily enriched during the coronavirus pandemic. It was, therefore, possible to access the content previously only physically accessible. Among the many initiatives, worthy of note is the Raphael exhibition at the Scuderie del Quirinale in Rome which displayed over two hundred masterpieces by the great master to the general public thanks to its online usability on the site and on social networks. (Note 12)

The virtual tours of the main museums in the world are also very interesting for art lovers. The images are of high HD quality and use 3D technology.

See, purely by way of simplification and not exhaustive, the application available for both iPhone and Android, proposed by the Guggenheim Museum in New York, has had considerable success. An interesting tour is the one that interests the Capitoline Museums in Rome, which can be accessed directly from the website with the possibility of choosing the language. The tour starts from Piazza del Campidoglio with the possibility to choose where to move thanks to the presence of directional arrows so that you can make the path step by step.

There is also the possibility of being able to reach your destination directly and more immediately using the "go directly to" function, choosing, for example, Palazzo Nuovo or Galleria Lapidaria. Once the selected destination has been reached, either step by step or directly, it is possible to access the audio guide, video, images, all in high definition.

Through Google's Art Project, it is possible to visit, from the comfort of one's home and at the most appropriate moment, over a thousand museums from all over the world. The project began in 2011 and could count on the works of seventeen muses the scattered throughout the world (two of which in Italy), to then reach one hundred and fifty-one over the following year, and finally over a thousand nowadays affecting museums throughout the globe. There is a direct link from the British Museum site in London that allows you to walk inside the museum to visit it. (Note 13)

Many virtual paths have been conveyed into a single container, namely Google Arts \& Culture, which is structured by foreground content, collections, and categories. It involves five thousand seven hundred thirty-six artists, two hundred thirty-one means of expression, one hundred twenty-one artistic movements, five hundred and seventyfive historical events, six thousand two hundred and seventy historical figures and nine thousand and seventyseven places. (Note 14) The "street view" section contained in the "Highlights", allows people to move by directing the "little man" of Google map within the chosen context allowing you to visit a certain view a museum located in the other part of the world or for example to climb, effortlessly, to the top of the Eiffel Tower in Paris and enjoy the view. The high-definition images are images with a resolution of up to seven Gigapixels or seven billion pixels.

\section{The Case of the Louvre Museum in Paris}

The Louvre Museum in Paris was founded on the tenth of August 1793 as Museèe Francais. Andrew McClellan offered an important contribution to the Louvre's history starting from the Luxembourg Palace as the first public art gallery opened to the public in France in October 1750. He set out how the museum, following the French Revolution, became a revolutionary symbol of the new Republic, witnessed its supremacy over kings. In 1796 it was renamed Musèe Central des Arts de la Rèpublique so to stress the relevance of the Republic. In 1803, Le Musée Central des Arts were recalled Musée Napoléon. From that time, several masterpieces enriched the collection due to confiscations royal collections coming from Austria, Germany, Italy, and Churches. Among the authors, Martina Griesser-Stermscheg highlighted that the museum, made of the royal collections declared national property, was a revolutionary event since it promised to disseminate knowledge amongst people. (Martina Griesser-Stermscheg, 2013) Despite the collapse of Napoléon, the Louvre remained a shift point for society and its demand for social right in Europe. (Note 15) The Louvre, thus, stimulated other European countries during the nineteenth century and several museums were set up due to Louvre's inspiration.

Currently, the Louvre boasts over thirty thousand items in sixty thousand square meters of floor space. It is the most visited museum in the world. This trend is confirmed over time. 
Table 1. According to the TEA/AECOM Theme Index and Museums Index, the Louvre Museum was at the first position of the museums' list with the highest attendance during 2019

\begin{tabular}{lcc}
\hline & Visitors in 2018 & Visitors in 2019 \\
\hline Louvre, Paris & 10.200 .000 & 9.600 .000 \\
National Museum of China, Beijing, & 8.610 .000 & 7.390 .000 \\
\hline Metropolitan Museum di New York & 7.360 .000 & 6.770 .000 \\
Vatican Museums & 6.756 .000 & 6.883 .000 \\
British Museum & 5.869 .000 & 6.208 .000 \\
Tate Modern, London & 5.829 .000 & 6.098 .000 \\
National Gallery, London & 5.226 .000 & 6.011 .000 \\
Natural History Museum, London & 5.000 .000 & 5.424 .000 \\
American Museum of natural history, NY & 5.000 .000 & 5.000 .000 \\
Hermitage, Saint Petersburgh & 4.957 .000 & 4.957 .000 \\
\hline
\end{tabular}

Table 2. According to Wikipedia, the list of museums with the highest number of visitors in 2012 boasted a different order. However, the Louvre Museum was the museum with more visits as achieving almost ten million visitors in 2012. Here is the list: (Note 16)

\begin{tabular}{lll}
\hline 1 & Louvre & 9.720 .000 \\
\hline 2 & Met, New York & 6.115 .000 \\
3 & Musei Vaticani & Almost 6.000 .000 \\
4 & Il British Museum & 5.575 .000 \\
5 & Tate Modern, London & 5.300 .000 \\
6 & National Gallery, London & 5.100 .000 \\
7 & Centro Pompidou & 3.800 .000 \\
8 & Victoria \& Albert Museum, London & 3.200 .000 \\
9 & MoMA, New York & 2.800 .000 \\
10 & Galleria degli Uffizi, Florence & almost 2.000 .000 \\
11 & Van Gogh Museum, Amsterdam & 1.500 .000 \\
12 & Guggenheim, New York & almost 1.200 .000 \\
\hline
\end{tabular}

Making a comparison between data in 2012 and 2019, it can be realised that some museums are not on the list of the most visited museums in the world anymore. What's more, The Louvre increased its appreciation amongst people with an increase of approximately five per cent. For that reason, it could be said that it is the most attractive museum in the world over time.

Besides the success of physical visits, Louvre has provided different typologies of access over the years according to society and technology changes. Being part of the society, museums have had to adapt "transforming themselves from islands to open systems which, as such, are characterized by relational nodes." (Lara Corona, 2020) Indeed, social media's usage has been gradually implemented in order to achieve active communication level. The Louvre's utilisation of Instagram has been significative before the coronavirus and after that. (Note 17)

Table 3. Starting from the previous list of the museums based on the number of visitors, here is the number of followers, in descending order, for the same museums

\begin{tabular}{llll}
\hline & Museum & September 2018 & December 2020 \\
\hline 1 & MoMA, New York & 4.000 .000 & $5, .200 .000$ \\
2 & Met, New York & More than 2.500.000 & 3.700 .000 \\
3 & Tate Modern, London & More than 2.000.000 & 3.700 .000 \\
\hline
\end{tabular}




\begin{tabular}{llll}
\hline 4 & Louvre, Paris & 2.000 .000 & 4.300 .000 \\
5 & Guggenheim, New York & Almost 2.000.000 & $2, .500 .000$ \\
6 & Il British Museum, London & 1.000 .000 & 1.900 .000 \\
7 & National Gallery, London & almost 1.000.000 & 1.700 .000 \\
8 & Victoria \& Albert Museum, London & 850.000 & 1.400 .000 \\
9 & Van Gogh Museum, Amsterdam & 850.000 & 1.800 .00 \\
10 & Centro Pompidou, Paris & More than 700.000 & 1.000 .000 \\
11 & Galleria degli Uffizi, Florence & 170.000 & 572.000 \\
12 & Musei Vaticani & 6.000 & 105.000 \\
\hline
\end{tabular}

The table shows how all the museums have increased their popularity with the public. The ranking of museums, made based on the number of followers, was generally held constant. Of note is the Louvre Museum, which has gone from fourth to second in just two years in the list of museums considered. The French museum has more than doubled the number of feedbacks on Instagram. Despite its success, the Louvre is not the museum with the biggest rate of growth since the Uffizi in Florence, and the Vatican Museums's impact was extremely remarkable.

The curious thing is that the ranking carried out in September 2018 by simple access to Instagram has developed so to create a different order of appreciation of the museums according to the number of the followers. Furthermore, this approval rating is not confirmed in the ranking drawn up according to the data concerning the number of "physical" visitors considered in relation to each of the museums referred to in the previous table.

So, how can the data of physical visits and number of Instagram followers be interpreted? First of all, it is necessary to highlight the fact that there is an important anomaly represented by the fact that the data refer to two different time contexts. The table relating to Instagram data refers to data from September 2018 and December 2020, that is still during the pandemic. Therefore, the information provided by the Instagram table shows that Instagram usage has increased significantly from the time before the first pandemic wave and the following time. Then, the data in the table related to "physical" visitors concern the year 2019. The visitor data trend has been supported by the information from the result of processing elaborated by The Art Newspaper and published in April 2013. Therefore, physical analysis and Instagram data concern different time.

For this reason, a correct analysis cannot be carried out from the comparison of the two tables, which would lead to making logical deductions. It would have been useful to have the two tables at the same time interval as well as its evolution over several periods. Nevertheless, it is argued that Louvre has increased its physical visits as well as Instagram appreciation over time. For that reason, the Louvre case study confirms that social media should attract online visits but also stimulate a subsequent physical visit. (Gökçe Özdemir \& Duygu Çelebi, 2017)

Table 4. Regarding Facebook, the Louvre has been using this social media actively. (Note 18) Here are the data of the Facebook profile

\begin{tabular}{lllllll}
\hline & December 2019 & March 2020 & April 2020 & May 2020 & June 2020 & December 2020 \\
\hline Number of posts & 26 & 20 & 22 & 22 & 22 & 22 \\
Number of likes & 56.865 & 66.272 & 107.386 & 62.187 & 79.338 & 61.128 \\
\hline
\end{tabular}

The table shows that the number of likes has increased before the first wave of the coronavirus and after, meaning from December 2019 and December 2020. Amongst a time of twelve months, the trend has recorded some changes. The peak of visits was reached in April, in the middle of the pandemic development. During that month, the Louvre almost doubled its likes. To sum up, it can be said that despite the unchanged number of Facebook post, the Louvre museum achieved more appreciation during the lockdown. 
Table 5. Moving on to visits to the official Louvre's web site, here are the data of the traffic to the louvre.fr in a seven-months-time of analysis during the year 2020

\begin{tabular}{cccccccc}
\hline & June & July & August & September & October & November & December \\
\hline Visits & 1.750 .000 & 2.000 .000 & 1.650 .000 & 1.800 .000 & 1.950 .000 & 1.700 .000 & 1.600 .000 \\
\hline
\end{tabular}

During these seven months, most of the traffic came from France (46\%), then from the United States of America $(13 \%)$, Brazil, Spain and the United Kingdom for about $3 \%$. The average visit duration was two minutes and eighteen seconds, with 2,58 pages for a visit and a bounce rate of $54,56 \%$. The website's access was mainly provided by search channels to the website $(55,78 \%)$ and directly to the website $(33,65 \%)$.

Table 6 . The access to the website through social media occurred only for $1,62 \%$ and was composed in the following way

\begin{tabular}{llll}
\hline Twitter & YouTube & Facebook & Pinterest \\
\hline $26,95 \%$ & $25,48 \%$ & $18,90 \%$ & $12,09 \%$ \\
\hline
\end{tabular}

Surprisingly, the table of the web site visits shows that immediately after the reopening post-Covid of the museum to the public the number of accesses to the website was significantly increased from 1.750 .000 to 2.000 .000 , meaning approximately thirteenth per cent. In the following months, the average number of visits, meaning 1.800.000, was approximately fourteen per cent bigger than the visits during the lockdown. Curiously, during November, when the Louvre was closed to the public, the average number of visits in comparison to the first closure decreased as much as the increase of the average visits during its opening. Overall, it could be said that the pandemic has not affected significantly the behaves of visitors on the website.

\section{Conclusion}

Museums are increasingly inclined to use new means of communication in order to increase accessibility to collections and interact with their audience. This new approach, which began a few decades ago, has shown itself to be a great opportunity for those museums which, closed due to restrictions due to the Covid-19 virus, have increased and improved their interaction with the public. This achievement has been demonstrated by the numerous virtual initiatives launched by the major museums in the world. Additionally, the paper shows positive feedback from the public. This result has been achieved through the case study of the Louvre Museums whose activity on Instagram and Facebook has recorded a relevant in the number of followers. This discussion concludes that technology opens up many opportunities for the dissemination of culture that breaks down the physical limits of the museum entity. This deduction is confirmed by the fact that in a situation of mandatory physical distancing, due to the Covid-19 virus, museums, like the Louvre, have been able to keep the active participation of the audience alive. Curiously, the essay concludes that there is no significant feedback related to the access to the website during the lockdown and the time the museum was opened. The research encounters some limitations. First of all, a single case study cannot provide a general picture of how museums used digital tools during the lockdown. Nevertheless, it might represent a crucial study due to the Louvre Museum's relevance in the world. Next, the present research only shows visitors' feedback through numerical data in terms of an increased number of likes, followers and views. Accordingly, the study does not answer whether people are interested in new forms of communication as tools for mere entertainment or curiosity or whether they are actually interested in museum collections. (Lara Corona, 2020) Therefore, future qualitative analysis might be conducted. Despite the limitations of this research, its results enrich literature in this field and might encourage future research involving other museums during the same time or in a different unusual context.

\section{References}

Neel Antara \& Shuvro Sen, (2020). The impact of Covid-19 on the museums and the way forward for resilience. Journal of International Museum Education, 2(1), 54-61.

Tsz Yin (Gigi) Au, Beth Chang, Michael Chee, Linda Cheu, Celia Datels, Lucia Fischer, Marina Hoffman, Olga Kondaurova, Kathleen LaClair, Jodie Lock, Jason Marshall, Sarah Linford, Jennie Nevin, Nina Patel, John Robinett, Judith Rubin, Matt Timmins, Chris YoshiiJudith Rubin, "Theme Index and Museums Index", TEA/AECOM, 2019

Binni Lanfranco and Giovanni Pinna, Museo. (1980). Storia e funzioni di una macchina culturale dal 500 a oggi, 
Garzanti, Milano.

Elisa Bonacini, (2016). Il Museo Salinas, paradosso del web marketing culturale, La comunicazione archeologica ai tempi dei social media, a museo chiuso. Archeomatica, 3, 12-17. https://doi.org/10.48258/arc.v7i3.1285

Verity Burke, Dolly Jørgensen \& Finn Arne Jørgensen (2020). Museums at home: Digital Initiatives in Response to Covid-19. in Årgang 6, nr. 2-, s. 117-123.https://doi.org/10.18261/issn.2464-2525-2020-02-05

Lara Corona (2020). Museology and Communication within the virtual museum. Ulakbile, 44(1), 26-31, https://doi.org/10.7816/ulakbilge-08-44-03

Francesca De Gottardo, Alessandro D'Amore, Valeria Gasparotti, Aurora Raimondi Cominesi, (svegliamuseo) (2014). Comunicare la cultura online: una guida pratica per i musei-progettazione di siti web, content management, social media e analisi dei risultati, 2014.

Alberto Del Bimbo, (2020). Ricognizione Musei post Covid 19, in A. Del Bimbo et al., Museiemotivi e motivi post Covid 19, Musei Emotivi Board, New Media for Cultural Herirage.

Philip Effiom Ephraim (2019). Louvre Abu Dhabi: Social media in marketing culture. Proceedings of the 5th World Conference on Media and Mass Communication, 5(1), 49-57. https://doi.org/10.17501/24246778.2019.5105

Yves Evrard \& Anne Krebs (2013). The authenticity of the museum experience in the digital age: The case of the Louvre. Journal of Cultural Economics, 37(3). https://doi.org/10.1007/s10824-017-9309-x

Fedora Filippi (2004). Manuale per la qualità dei siti web pubblici culturali, Ministero per i beni e le attività culturali- Progetto Minerva.

Ion Gil-Fuentetaja \& Maria Economou (2019). Communicating Museum Collections Information Online: Analysis of the Philosophy of Communication extending the Constructivist approach. Journal on Computing and Cultural Heritage, 12(1), 3. https://doi.org/10.1145/3283253

De Gottardo, F., D'Amore, A., Gasparotti, V., \& D’Eredità (2014). Comunicare la cultura on line: una guida pratica per i musei. Progettazione di siti web, content management, social media e analisi dei risultati, a cura di F. De Gottardi, A. D’Amore, V. Gasparotti, A. Raimondi Cominesi, 66-70.

Claudia Giraud (April 2020). Ermitage online: boom con undicimila visitatori il primo giorno in diretta dalle sale del museo, Artribune, 1.

Martina Griesser-Stermscheg (2013). Tabu depot: Das Museumsdepot in Geschichte und Gegenwart, Konservierungswissenschaft. Restaurierung. Technologie, Boehlau Verlag, Bohlau, 2013, ISBN 9783205788942.

Natalia Grincheva (2014). The Online museum: a placeless of the "Civic Laboratory". Anthropology Review, 8(1). https://doi.org/10.14434/mar.v8i1.3187

Linda Kelly (2013). Museum communication and social media, in Kirsten Drotner, Kim Christian Schrøder, The Connected museum in the world of social media, Routledge, New York.

Suzanne Keene (2014). Museums and the Digital: the view from the Micro Gallery, Conference: Electronic visualization and the Arts 2014. https://doi.org/10.14236/ewic/EVA2014.30

Neil Kotler, Philip Kotler \& Wendy Kotler (2008). Museum Marketing and strategy, Wiley \& Sons, 2008

Nicolette Mandarano (2019). "Musei e media digitali" Carocci, Milano, 2019, EAN 9788843095988

Andrew McClellan (1999). Inventing the Louvre, University of California Press, Berkeley, Los Angeles, London. ISBN 9780520221765.

Trilce Navarrete (Jun. 2018). On the Economics of Physical and Digital Collections in Museums. Uncommon Culture. 7, 1/2, 57-73.

Trilce Navarrete \& Elena Villaespesa (2020). Digital Heritage Consumption: The case of the Metropolitan Museum of Art. Magazén, 1(2), 223-248, https://doi.org/10.30687/mag/2724-3923/2020/02/004

Network of European Museum Organisations. (2020). Survey on the impact of the COVID-19 situation on museums in $\quad$ Europe. Retrieved from https://www.nemo.org/fileadmin/Dateien/public/NEMO_documents/NEMO_COVID19_Report_12.05.2020.pdf

Gökçe Özdemir \& Duygu Çelebi (2017). A social media framework of cultural museums. Advances in Hospitality and Tourism Research, 5(2), 101-119, https://doi.org/10.30519/ahtr.375248 
Sabina Rosso, Romina Surace \& Antonia Silvaggi (2016). "Museo del futuro", Symbola, Roma, Isbn 9788894297614

Paolo Savona, Francesco Bellotti, Umberto Colombo, Gianpaolo Fabris, Vittorio Grilli, Salvatore Vicari "Rapporto innovazione e tecnologie digitali in Italia", Centro studi del Ministro per l'Innovazione e le Tecnologie, Roma, 2002, 87-89.

Ole Smordal \& Dagny Stuedahl (2011). Designing for young visitorso co-composition of doubts in Cultural $\begin{array}{llll}\text { Historical Exhibitions. } & \text { Computer 215-223. }\end{array}$ https://doi.org/10.1016/j.compcom.2011.07.008

Monika Stobiecka (2019). Digital Escapism: How Objects Become Deprived of Matter. Journal of Contemporary Archeology, 5(2), 194-212. https://doi.org/10.1558/jca.34353

Villaespesa, Elena \& Navarrete, Trilce (2019). Museum Collections on Wikipedia: Opening Up to Open Data Initiatives. MW19: MW 2019. Published on January 14, 2019. Consulted January, 4, 2021. Retrieved from https://mw19.mwconf.org/paper/museum-collections-on-wikipedia-opening-up-to-open-data-initiatives/

Alexandra Weilenmann, Thomas Hilman \& Beata Jungselius, (2013). Instagram at the Museum: Communicating the Museum experience through social photo sharing, CHI13, proceedings of SIGCHI Conference on Human factors in computing systems. https://doi.org/10.1145/2470654.2466243

Michela Zingone (2019). Instagram as Digital Communication tool for the Museums: A reflection on Prospectives and Opportunities through the Analysis of the Profiles of Louvre Museum and Metropolitan Museum of New York. European Journal of Social Science, Education and Research, 6(3), 53-63, https://doi.org/10.26417/ejser.v6i3

\section{Web sites}

https://wearesocial.com/blog/2020/04/digital-around-the-world-in-april-2020

https://it.wikipedia.org/wiki/Lista_dei_musei_d\%27arte_pi\%C3\%B9_visitati_al_mondo

http://www.minervaeurope.org/publications/qualitycriteria-i/indice0512/feliciatiwebculturale.html

https://www.britishmuseum.org/collection

https://www.moma.org/collection/

https://artsandculture.google.com/

https://www.macitynet.it/cultura-mobile-italy-by-art-nuova-app-mibact-per-ios/

https://www.scuderiequirinale.it/pagine/raffaello-oltre-la-mostra

\section{Notes}

Note 1. Prosumer is the term created by putting together the words producer and consumer to emphasise the active collaboration of the consumer who, thus, is also a producer. Alvin Toffler mentioned it in his book "The third wave". See Nicolette Mandarano, "Musei e media digitali" Carocci, Milano, 2019.

Note 2. She suggested the usage of the $5 \mathrm{~W}$ rules of communication which encompass whom (target of the recipients), what (museums want to share with the audience), where (every social media offers different advantages and encounters some limitations; so, Facebook allows a bigger content than Twitter), when (communication should be provided continuously, not nagging), why (the purpose of the communication, such as share exhibitions, the online collections, events and so on).

Note 3. Word of mouth helps to address consumers' opinions. Therefore, it is a key element for the decisionmaking process; suppliers of goods and services are supposed to pay attention to it.

Note 4. Parameters like number of followers, number of likes, and the number of online users are assessed as marketing strategy variables. See Natalia Grincheva, the Online museum: A placeless of the "Civic Laboratory". Anthropology Review, 8(1), 2014.

Note 5. https://wearesocial.com/blog/2020/04/digital-around-the-world-in-april-2020, retrieved on 7 September 2020.

Note 6. Mandarano reported that $79 \%$ of museums have a Facebook account. 
Note 7. Mandarano defines Instagram as a valid tool to show museum collections because it allows people to share images.

Note 8. http://www.minervaeurope.org/publications/qualitycriteria-i/indice0512/feliciatiwebculturale.html

Note 9. https://www.britishmuseum.org/collection, consulted on 2 December 2020.

Note 10. https://www.moma.org/collection/ consulted on 8 December 2020.

Note 11. Authors Navarrete and Villaespesa set out an interesting case study about the Metropolitan Museum of Art's digital heritage consumption. Their results highlighted that channels like Wikipedia show a new digital consumption which stresses the collection's information value. See Trilce Navarrete, Elena Villaespesa, Digital Heritage Consumption: The case of the Metropolitan Museum of Art, in Magazén, 1(2), 2020, 223-248.

Note 12. https://www.scuderiequirinale.it/pagine/raffaello-oltre-la-mostra consulted on 4 December 2020

Note 13. http://www.britishmuseum.org/

Note 14. https://artsandculture.google.com/ consulted on 1 September 2020.

Note 15. The middle class developing the idea of "democracy" demanded more social rights, which involved a new Museum concept for people to replace the old Kunstkammer just for few people. Therefore, in Europe, many royals set out museums with their collection for the general public and started to use them as a communication tool (Binni \& Pinna, 1980: 55).

Note 16. https://it.wikipedia.org/wiki/Lista_dei_musei_d\%27arte_pi\%C3\%B9_visitati_al_mondo consulted on 17 October 2020.

Note 17. By and large, Museums in France were closed from the thirteenth of march to the fifth of July and from the twenty-ninth of October to the fifteenth of December 2020 due to the coronavirus pandemic.

Note 18. Louvre has an important thirty-years-agreement with the Abu Dhabi Louvre. Ephraim (see Philip Effiom Ephraim, Louvre Abu Dhabi: Social media in marketing culture, conference on media and Mass Communication, 5 (1) 2019. 49-57) wrote how this Institution has used social media to attract the audience and has been able to promote arts in the United Arabs Emirates. The Museum gave an important communication via Facebook by posting the news that the Abu Dabhi Department of Culture and Tourism had decided to postpone the long-awaited public exhibition of the "Salvator Mundi" of Leonardo da Vinci. The painting should have been exhibited on 18 September 2018, and many, both experts in the field and simple art lovers had already purchased tickets. This decision was probably taken after the controversy unleashed on the authenticity of the painting that sees the author of the work no longer in Leonardo da Vinci but in Bernardino Luini, a simple assistant. And all this happened after the Arab museum had managed to obtain the prestigious work after twenty minutes of an auction at Christie's in New York for well over 450 million dollars. As Abu Dabhi's English-language newspaper "The National" reports, "speculation suggests the museum might be waiting for its first anniversary, on November the eleventh". All these controversies give the immediate perception of the fact that it was an important communication. Approximately two weeks before the event, the Louvre Abu Dabhi gave this news, and to do so, it chose a tool that is immediately received by the masses, which is Facebook.

\section{Copyrights}

Copyright for this article is retained by the author(s), with first publication rights granted to the journal.

This is an open-access article distributed under the terms and conditions of the Creative Commons Attribution license (http://creativecommons.org/licenses/by/4.0/). 